\title{
Papirløs fremtid for medisinske tidsskrifter?
}

Selv om ryktene om papirmedienes død er sterkt overdrevet, er publisering på papir bare en av mange måter å formidle informasjon på. Web, mobil og lesebrett er reelle utfordrere. I januar begynte $B M J$ å publisere kun en sides oppsummering av sine originalartikler i papirutgavene (1). Da hadde de allerede et par år kun publisert utvalgte artikler i papirutgaven, mens de publiserer kontinuerlig på nett. Den korte versjonen av originalartiklene er én av i alt tre versjoner av artikkelen. Nettversjonen inneholder lenker og annen nettfunksjonalitet. I tillegg produseres en pdf-versjon av den lange versjonen med tradisjonell papirlayout (2). På nettet er utgaven tonet ned. Den er bare en av flere veier inn i innholdet.

NEJM har valgt å se nettversjonen og papirversjonen som komplementære (3). Likevel satser de stort på innhold produsert spesielt for nettutgaven. Artikler blir tilrettelagt med animasjoner og filmsnutter som bidrar til å øke forståelsen av budskapet. De produserer også selvstendige interaktive artikler. Uavhengig av hvor innholdet skal publiseres, går det gjennom samme fagfellevurdering og redaksjonelle behandling. Allerede fra 2002 var NEJM tilrettelagt for mobile enheter.

Da Tidsskriftet kom på nett i fulltekst i 2000, ble nettutgaven sett på som en tilleggsfunksjon (4). Men nå har den vært arkivversjonen og hovedversjonen i noen år allerede. I 2003 begynte vi å publisere små deler av innholdet kun på nett, slik som de engelske sammendragene, enkelte tabeller og figurer (5). Nettutgaven har alltid hatt funksjonalitet som hyperlenker og er stadig blitt mer sofistikert. Blant annet lenker vi til Norsk legemiddelhåndbok alle steder virkestoffer er omtalt. Fra 2008 har vi publisert videoer som figurer, og i 2009 publiserte vi vår første fagfellevurderte interaktive artikkel (6). Fra 2009 innførte vi også doi-numre på artikler. Doi står for «digital object identifier» og er en effektiv og entydig referering til elektroniske artikler (7).

Konvergens er en trend som har preget medieutviklingen de siste årene. De tette skottene som tidligere eksisterte mellom det skrevne ord, TV og radio viskes ut på nettet. Ulike typer teknologi smelter også sammen. En mobiltelefon er ikke lenger bare er en telefon, men en liten datamaskin. Dette har også påvirket Tidsskriftets utvikling. I 2007 ble Tidsskriftets podkast lansert. Januar 2010 fikk vi vår egen web-TV i form av en kanal på YouTube. YouTube er et sosialt medium der innholdet kan deles, kommenteres og poengberegnes («rates»). Fremveksten av sosiale medier har i likhet med konvergens hatt vesentlig betydning for medieutviklingen. For tidsskriftene innebærer sosiale medier en ny måte å distribuere og diskutere innholdet på. Det er viktig, fordi diskusjon og utveksling av informasjon er så avgjørende for god medisinsk praksis. Fra 2010 er Tidsskriftets innhold tilrettelagt for deling og diskusjon i sosiale medier som Facebook, Twitter og Delicious. Tidsskriftet har lenge brukt medlemsportalen Min side både som en temabasert inngang til innholdet og som et sosialt medium der leserne kan diskutere

(8). Når lesere deler en av våre artikler med alle i sitt nettverk, når den ut til nye lesere. Merkevaren er den samme, men kanalen er en annen.

Vi har kunnet lese e-bøker på engelsk i flere år, og lesebrettene blir stadig bedre og billigere. Bokbransjen i Norge er teknisk sett klar for å lansere norsk litteratur for lesebrett, men holder igjen på grunn av uklarhet rundt hvorvidt e-bøker skal momsbelegges eller ikke. E-bokens suksess antas å avhenge av lav pris, noe som ikke vil kunne sikre samme inntjening $i$ alle de leddene den norske bokbransjen består av. Samtidig ser vi at Dan Browns nyeste bestselger på engelsk nå selger mer som e-bok enn på papir i nettbokhandelen Amazon (9). Tatt i betraktning de medisinske tidsskriftenes evne og vilje til å tilpasse seg web, er det lite som tyder på at de vil velge samme proteksjonistiske linje. Lesebrett og mobil gjør det mulig å ha med seg klinisk relevante artikler i praksisnære situasjoner, og er derfor kanaler vi ikke kommer utenom hvis vi skal ta målsettingen vår på alvor.

Det er flere argumenter for å velge kontinuerlig publisering og mer ekstreme varianter av prinsippet «electronic long - paper short», slik som $B M J$ har gjort. Tiden fra en artikkel er godkjent til den blir tilgjengelig for publikum kortes ned. Trykking og særlig distribusjon av papirutgaven er kostbart. Selv om kvalitetssikringen er den samme, er nettet en billigere kommunikasjonsform enn papir. Originalartikler er ofte om spesialiserte emner og retter seg ikke mot alle leserne av et generelt medisinsk tidsskrift. Én side kan kanskje være nok til å fange de rette lesernes interesse for å oppsøke innholdet i nettutgaven? NEJM er et eksempel til etterfølgelse når det gjelder utnyttelse av nettets mange muligheter for blant annet god visuell formidling av medisinsk kunnskap. Deres satsing på unikt innhold som blant annet animasjoner og videoer i nettutgaven, og tidlige tilrettelegging for mobile enheter, viser at merkevaren $N E J M$ står sterkt også uten papir.

Lite tyder på at verken $B M J$ eller $N E J M$ vil legge ned papirutgavene. Mens $B M J \mathrm{~s}$ papirutgave går i retning av magasin, fastholder NEJM den mer tradisjonelle versjonen av et papirbasert medisinsk tidsskrift. Vi har ingen planer om å slutte å utgi Tidsskriftet på papir. Samtidig vil vi fortsette å utvikle og tilrettelegge merkevaren Tidsskriftet flermedialt og plattformuavhengig. Leserne vil avgjøre om nye plattformer etter hvert erstatter eller fortsetter å komplementere gamle.

\section{Stine Bjerkestrand \\ stine.bjerkestrand@legeforeningen.no}

Stine Bjerkestrand (f. 1972) er utviklingsredaktør i Tidsskriftet og cand.mag. med journalistikk, medievitenskap og statsvitenskap i fagkretsen.

\section{Litteratur}

1. Godlee F. A few changes for 2010. BMJ 2009; 339: b5632

2. The BMJ's publishing modell. http://resources.bmj.com/bmj/about-bmj/ about-bmj/policies/the-bmjs-publishing-model (21.3.2010)

3. Campion E, Anderson K, Drazen J. Advances in our electronic pages. N Engl J Med 2002; 346: 362 .

4. Strand G. Tidsskriftet for alle i fulltekst på Internett. Tidsskr Nor Lægeforen 2000; 120: 1367.

5. Nesje SB. Ny drakt og nye Internett-tilbud. www.tidsskriftet.no/?nyhe_id=246 (23.3.2010).

6. Taraldsen T. Benign paroksysmal posisjonsvertigo. Tidsskr Nor Legeforen 2009; 129: doi: 10.4045/tidsskr.09.07D1

Welcome to the DOI-system. www.doi.org/ (21.3.2010).

8. Haug C. Kaoskontroll og kontaktflate. Tidsskr Nor Legeforen 2008; 128: 2047.

Aftenposten. Selger flest bøker digitalt. www.aftenposten.no/kul_und/ article3274781.ece (21.3.2010). 